\section{Developing countries: whose views?}

SIR

Having often bemoaned that bioethics in developing countries is a severely neglected subject, and that academicians from these nations rarely get the opportunity to expound their views and express their concerns, I was excited at the title of Professor Olweny's paper in the fournal of Medical Ethics 1994; 20: 169-174, entitled, Bioethics in developing countries: ethics of scarcity and sacrifice.

Admittedly, it was unsettling to see such a topic emerge from a country that by no standards qualifies as underdeveloped [Canada], and this may be a reason why some points of criticism came forth so readily. To begin with, in less developed countries we would not consider ethics as a science, perhaps because philosophies are so highly infected with religious and political doctrines. Second, we make it a point to consider bioethics as being much more than a problem of 'medical values and progress', because many non-medical aspects of biology need attention, such as, to name but two, population ethics and the depletion of natural resources.

Professor Olweny is unhappy to note 'a new form of medical ethics ... neither rational nor philosophical'. But he then states that ' $[R]$ esources allocation is the primary responsibility of health care facility'. Now, responsibility is an ethical term, so that this 'new form' of medical ethics seems called for after all, to counsel the rich and look after the poor.

To underdevelopment. Structural Adjustment, in fact a mammoth socio-economic programme, must, in the view of Olweny, be buttressed by 'progress in other areas, such as education'. This means that the way out of underdevelopment is to develop, which is probably correct but hardly to be considered a bioethical proposition.

Olweny suggests an agenda for health care in developing countries which includes, inter alia (sic): moving away from 100 per cent governmental funding; expansion of health care services to reach rural areas; community participation in health promotion, and the reintroduction of 'ethics ... back into health care practice and into society itself'.

This is a sound public health care programme, but I am not sure it contains specifically bioethical issues. And if [bio] ethics were something like a science, and I will agree that it is at least a disciplined academic endeavour, then its premises should be clearly stated and differentiated from other disciplines such as public health, sociology, politics, economics and so on.

In sum, let me contrapose a brief alternative agenda of what seem to be the more pressing needs of bioethics in developing countries, agreeing with Olweny that priority is due to the issue of intervention and extension of the right to health care, and governmental support thereof. Additional topics are: the reassessment of autonomy in countries with strong paternalistic traditions and severe cultural inequalities; consideration of the role of the family beyond the anecdotal discrepancies between patients and kin, but rather in the tradition of tribal ties where the family's social action is interwoven with that of each of its members; technical and scientific growth in economically fragile environments; the influence of academia in legislative procedures pertaining to bioethical issues, considering the wide political spectrum and often harsh ways of wielding power that may lead to laws that disregard public opinion and the will of majorities, and individual and demographic aspects of human reproduction.

My point is that underdeveloped countries are better equipped to assess their needs than outside observers, and that well meant but distant proposals will probably re-affirm paternalism and perpetuate dependence. To be honest I do not question Professor Olweny's concern and good intentions, but I believe such topics should be addressed from the other end of the road or, something which is sorely missed and which could possibly prove to be quite fruitful, in joint academic ventures.

MICHAEL H KOTTOW, MD Casilla 37 Correo 10, Santiago, Chile

\section{The ethics of} ignorance

SIR A guest editorial, The ethics of ignor ance, appeared in the journal (1), writ? ten by the editor of the British Medicat fournal, Richard Smith. I find the article very interesting and though provoking. The article focuses on th 'evidence of poor evidence' and dist cusses various limitations and pitfalls in the creation of established knowledge $\vec{\rho}$ I would like to point out a paradox in the paper that in my opinion illustrategs that one has to be very careful whe one presents figures or facts.

In his article Richard Smith quotês two colleagues, Professor Eddy, 'añ American cardiothoracic surgeon wit $\vec{G}$ a $\mathrm{PhD}$ in mathematics' and S审 Douglas Black, 'a former president of the Royal College of Physicians of London'. These distinguished colleagues 'argue that only about 15 pe乃' cent of medical interventions are supported by solid scientific evidence in other words, 85 per cent, are not

This figure, 15 per cent, was quoted in an article in the fournal of ghe $^{\mathrm{C}}$ Swedish Medical Association in 1998 as an established measure of the uneer tainty of medical knowledge. Sitics this figure is a key figure in this discus sion, I find it mandatory that tho evidence is solid and beyond doubt. Iक the context of medical uncertainty, $\mathbb{R}$ would have been appropriate to stres $\overrightarrow{\vec{S}}$ the uncertainty with which we esti mate the degree of this uncertaint and to discuss how the colleagues. referred to could 'argue' in support of: it. Instead of describing the standin of the two referees, references shoulit have been presented. Without suct. information, critical analysis is nog possible and, thus, counterproductive to the purpose of the editorial.

\section{References}

(1) Smith, R. The ethics of ignor ance. Fournal of medical ethiass 1992; 18: 117-118.

Karolinska Institute
GUNNAR AKNER, MD, PhD
Department of Medical Nutrition
Huddinge University Hospital F6
Novum, S-141 86 Huddinge, Swede?

